\title{
Non-sustainable prices as an obstacle for sustainable development of mining industries
}

\author{
Anna Lozhnikova ${ }^{1 *}$, Elena Chausova $^{1}$, Elena Andrienko ${ }^{1}$, and Alexandra Nabiullina ${ }^{1}$ \\ ${ }^{1}$ National Research Tomsk State University, 63405036 Lenin ave., Tomsk, Russia
}

\begin{abstract}
In this paper the activity of Russian mining companies is analysed in terms of global market's trends, pricing policies, full-cycle production from extraction and preparing iron ore and to its deep processing, and as well as sustainable development. The pricing policy of the Federal Antimonopoly Service of the Russian Federation is criticised: monopolists in metal and mining industry sell its production in the domestic market based on the LME prices expressed in USD. The dynamics of the LME Official Prices Cash Seller \& Settlement for aluminium and zinc is explored and described. The authors focus on the effect of "double volatility" of prices for ingots connected with low addedvalue goods as well as the USD/RUB exchange rate. There is no connection between production and research, which undermines stable development of the mining industry. The main reason for the foundation of The Russian Aluminium Association is discussed. In the conclusion, it is emphasised that the Russian government will have to review its policy in regulating the mining industry and switch to import substitution because of the current political and economic situation on the global metal markets.
\end{abstract}

\section{Introduction}

The Russian metals and mining industry (Norilsk Nickel, Rusal, EVRAZ, NLMK Group, RSC Severstal, ALROSA, UMMC-Holding Corporation, SUEK, HC Sds-Ugol, Polyus, NordGold) carries out its activity in Siberia after rapid privatisation of the industry [1]. In the USSR, those companies were owned by the state and performed a full-cycle production from extraction and preparing iron ore to its deep processing.

\section{Materials and Methods}

Non-ferrous metal prices have been influenced by a number of traditional factors such as aggregate supply and demand and metal exchange stock levels which closely correlate with the exchange prices for corresponding metals. However, the mid 2000s saw a huge influx of investments into non-ferrous metal markets. The influx was determined by investors' interest in short-term deals considering metals as high-yielding assets. A big role in their

\footnotetext{
* Corresponding author: tfg@mail.ru
} 
pricing was played by the speculative component. Various financial assets, exchange rates, and prices for other exchange commodities started directly affecting non-ferrous metal prices. The London Metal Exchange (LME) is the world center for industrial metals trading. Today, metal supply contracts are dominating the metal exchange rather than "real" metals. But this the place where world prices for metals are formed. LME official prices are used as the global reference for physical contracts. They are considered reasonable and referred to by non-ferrous metals producers in substantiating their pricing policies.

An example of such a pricing based on the LME quotes is the Russian aluminum and zinc markets. Aluminium is mainly consumed by packaging, construction, and transport (automotive, aircraft, and shipbuilding). $2 / 3$ of aluminium products is consumed by these industries. These are investment goods and their production provides the population with high-performance jobs. RUSAL is the only aluminium producer in Russia, an exportoriented economic entity. According to the Principles of the Federal Antimonopoly Service of the Russian Federation (FAS Russia) [2], RUSAL sells primary aluminum in the domestic market, based on the LME aluminium price expressed in USD.

Ural Mining and Metallurgical Company (UMMC) is a monopolist in zinc production. Consumers entirely depend on the pricing policy of the monopolist company, which is similar to the RUSAL case [3]. Throughout the world, zinc consumption is rising due to increasing production of galvanised iron sheet widely used in construction and automotive industries [4-6].

\section{Results and Discussion}

Let's thoroughly analyse the metal price dynamics over the past four years.

Figure 1 shows the dynamics of the LME Official Prices Cash Seller \& Settlement for aluminium and zinc (USD/tonne) from January 2, 2014 to March 29, 2018. Converted in the USD/RUB exchange rate, prices for the metals in RUB/tonne are presented in Figure 2. As we can see in the charts, unlike USD prices, RUB prices for the metals have been rising all the time. It is connected with the ruble fall in 2014-2015 you can observe in Figure 3.

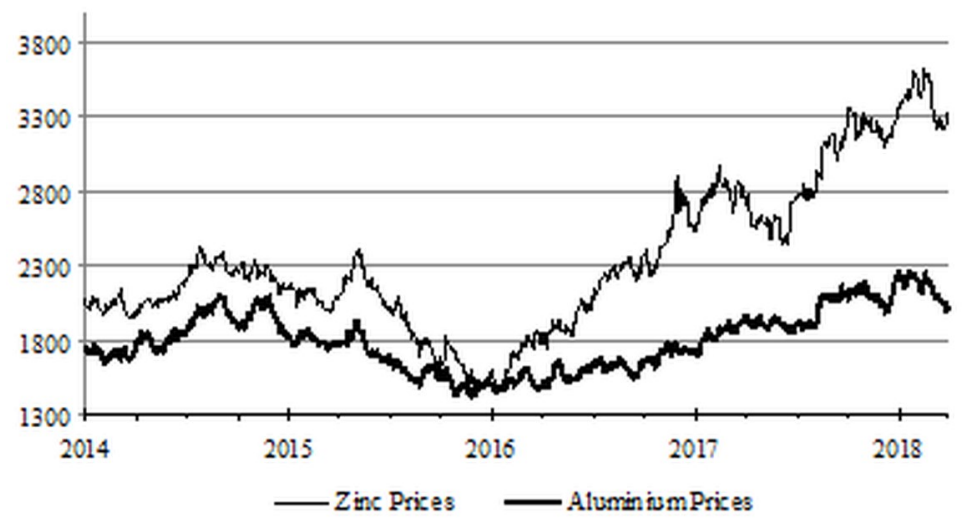

Fig. 1. The LME Official Prices, Cash Seller \& Settlement

In the fourth quarter of 2015, LME aluminium price reached an average of $1495 \mathrm{USD} /$ tonne, demonstrating a $24 \%$ decrease compared to $1966 \mathrm{USD} /$ tonne in the fourth quarter of the prior year. However, the falling ruble in 2014-2015 (Fig. 3) maintained a high stable average ruble price for aluminium at $98368 \mathrm{RUB} /$ tonne in the fourth quarter of 2015 with a $6.2 \%$ increase year on year. At the same time, the average price of 
aluminum in 2015 increased by $40.3 \%$, reached $100981 \mathrm{RUB} /$ tonne compared with the average price of 2014, i.e. $71950 \mathrm{RUB} /$ tonne.

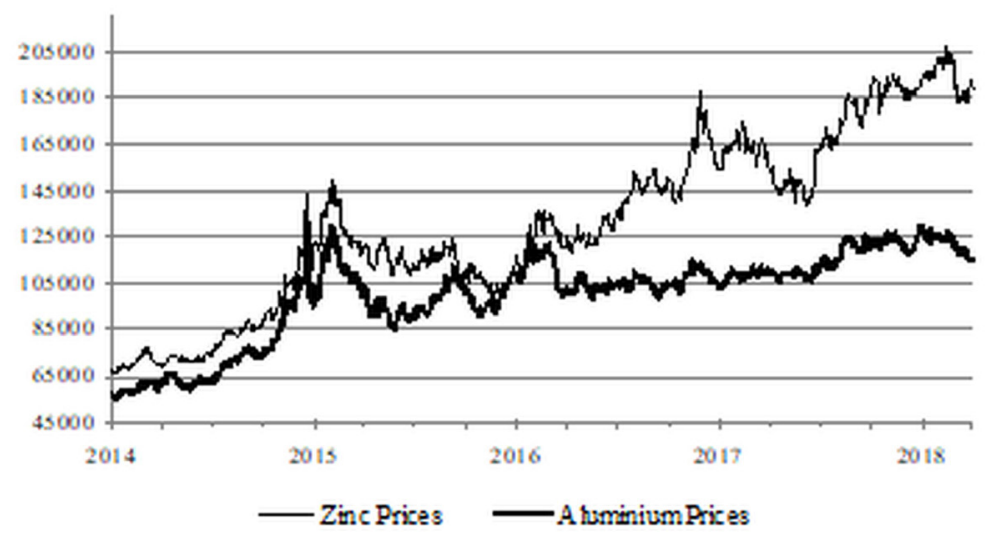

Fig. 2. The LME Official Prices, Cash Seller \& Settlement, RUB/tonne.

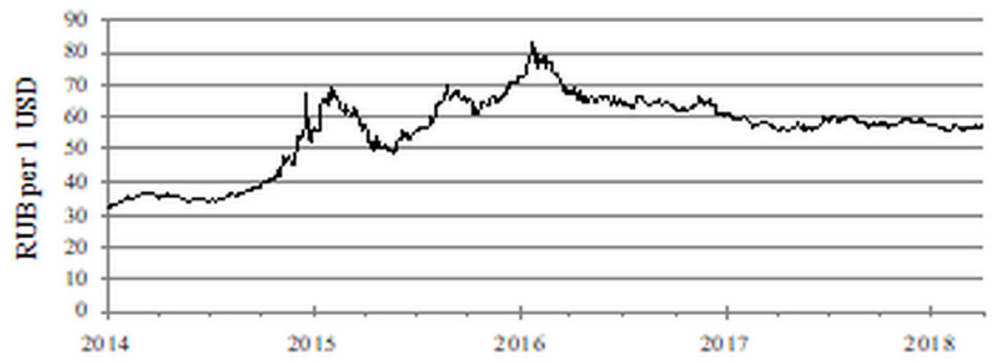

Fig. 3. Official exchange rate USD/RUB. Source: Bank of Russia, http: //www.cbr.ru/eng.

In 2017, the LME aluminium price increased by $22.6 \%$ to an average of $1969 \mathrm{USD} /$ tonne as compared to $1606 \mathrm{USD} /$ tonne in 2016. The main driving factors for the price growth were supply-side reforms in China's aluminium industry, Chinese environmental protection and a steady reduction of aluminium stocks at the LME. Given weak exchange rate of the ruble in this period (Fig. 3) aluminium price in rubles also tends to increase. Fig. 4 represents the dynamics of 20-day historical volatilities calculated as rolling annualised 20-day standard deviations in logarithmic returns, based on daily ruble zinc and aluminium prices.

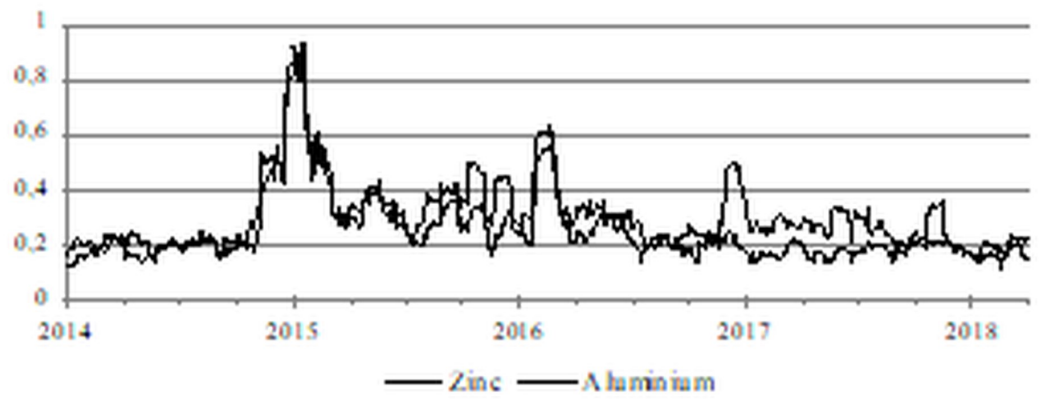

Fig. 4. Annualised 20-day historical volatility. 
The chart illustrates that volatilities were very high in early 2015 reaching their highest level nearly $90 \%$. In the past two years, volatilities remain quite stable. Since the 2 nd quarter of 2016 , the average aluminium volatility has been $19.7 \%$, average zinc volatility equals to $26.3 \%$. It should be noted that metals prices are quite volatile nowadays. Thus, we face the effect of "double volatility" of metal prices caused by the volatility of LME prices in USD, on the one hand, and currency-related volatility, on the other hand.

We think that non-sustainable LME prices are a stumbling block for sustainable development in mining industry and high-tech industries of the Russian national economy. According to the Federal State Statics Service, a steadily low investment share in machinery, equipment, and means of transportation in Russia has been observed for 17 years (Table 1).

Table 1. Investments in fixed capital by types of fixed assets in Russia.

Source: http://www.gks.ru/wps/wcm/connect/rosstat_main/rosstat/en/figures/investments/

\begin{tabular}{|c|c|c|c|c|c|c|}
\hline & $\mathbf{2 0 0 0}$ & $\mathbf{2 0 1 0}$ & $\mathbf{2 0 1 4}$ & $\mathbf{2 0 1 5}$ & $\mathbf{2 0 1 6}$ \\
\hline & \multicolumn{5}{|c|}{ In bln. rubles } \\
\hline Total & 1165.2 & 9152.1 & 13902.6 & 13897.2 & 14639.8 \\
\hline including in: & & & & & \\
\hline dwellings & 132.0 & 1111.7 & 2014.4 & 2172.8 & 2254.3 \\
\hline $\begin{array}{c}\text { buildings (except residential) } \\
\text { and structures }\end{array}$ & 502.2 & 3962.8 & 5665.3 & 6069.1 & 6618.1 \\
\hline $\begin{array}{c}\text { machinery, equipment, } \\
\text { means of transportation }\end{array}$ & 426.6 & 3472.7 & 5052.0 & 4375.1 & 4480.7 \\
\hline other & 104.4 & 604.9 & 1170.9 & 1280.2 & 1286.7 \\
\hline & & \multicolumn{5}{|c|}{ In percent } \\
\hline Total & 100 & 100 & 100 & 100 & 100 \\
\hline including in: & 11.3 & 12.2 & 14.5 & 15.6 & 15.4 \\
\hline dwellings & 43.1 & 43.3 & 40.8 & 43.7 & 45.2 \\
\hline $\begin{array}{c}\text { buildings (except residential) } \\
\text { and structures }\end{array}$ & 36.6 & 37.9 & 36.3 & 31.5 & 30.6 \\
\hline $\begin{array}{c}\text { machinery, equipment, } \\
\text { means of transportation }\end{array}$ & 9.0 & 6.6 & 8.4 & 9.2 & 8.8 \\
\hline other &
\end{tabular}

Due to the ruble's fall, in early 2015 the Russian aluminium market found itself in an extremely difficult situation. There was a dramatic increase in ruble prices for primary aluminium and alloys (Fig. 2), which led to a significant increase in the cost of aluminiumbased products in the automotive, aircraft, and shipbuilding industries. Demand from the construction industry shrank. Domestic producers of investment goods started questioning price binding to LME. Domestic manufacturers (machinery, equipment, and means of transportation) appealed to the FAS of Russia and asked to contribute to the solution of the problem, review the pricing policy, and take measures to reduce prices. In 2015, to enhance the development of adjacent Russian aluminium-consuming industries like air construction, automotive, ship construction, railway car construction, energy, oil and gas sectors, and construction, The Russian Aluminium Association was established. Judging by soaring USD and EUR in 2014-2015, The Russian Aluminium Association suggested switching to settlements in the Russian currency and called on the monopoly producer RUSAL to fix the aluminium price in rubles to support the domestic market. This suggestion sounds quite reasonable since the salary of the RUSAL employees, as well as the largest expenditure for electricity - is formed in rubles. The Ministry of Industry and Trade of the Russian Federation, considering the price dispute between car producers and metal suppliers, recommended the latter to exclude the binding of prices for their products to exchange quotations nominated in foreign currency on the domestic market. The recommendation referred to all exchange metals: zinc, aluminium, and others. 
Unfortunately, the Russian government supports the idea to provide RUSAL with a foreign exchange earnings rather than ruble profit. In 2013, Russia's Prime Minister Dmitry Medvedev ordered his government to seek an opportunity to create a state aluminium fund. He suggested the fund purchasing aluminium at 50 million rubles. Deputy Prime Minister Arkady Dvorkovich also supported the idea of starting an aluminium fund of the Russian Federation: "I have ordered to work out a mechanism for starting a fund. I have a rough idea what sources to use but the mechanism must be created so that we could use it in a critical situation if we have financial resources", said he.

Because of such an economic policy, RUSAL's main partner is Alcoa. The Russian company made an agreement with the American partner in the 1990s. According to the agreement, RUSAL serves as a raw material supplier. It does not produce export high added-value goods but ships metal ingots. Therefore, the largest portion of products produced in Siberian RUSAL plants is exported as aluminium ingots. Therefore, at present, most of the products produced at the Siberian RUSAL plants are exported abroad as semifinished products. Significant amount of that metal returns to Russia as finished hightechnological high added-value products. For example, the analysis of the structure of import of products from aluminium alloys shows that more than a half of them accounts for the automotive industry. Another example, new foundry technologies have not been developed in recent years, since 10 research institutes engaged in foundry production are liquidated by the privatisation system. Research is done by foundry departments at universities that lack advanced devices and equipment. The number of researchers in the foundry production has dropped from $8 \%$ to $0.2 \%$ for the last 15 years. There is no connection between production and research, which undermines stable development of the mining industry. There are no modern projects contributing to the development of the Siberian regions, home to the main aluminium stock and high-technology machinery production sites, large aviation plants (Novosibirsk, Irkutsk, Ulan-Ude, Komsomolsk-onAmur, Arsenev), space industry (Omsk, Krasnoyarsk, Zheleznogorsk), railway industry and others. Nowadays, Russia is striving to recover the production of civil planes and take up $10 \%$ of the world's market by 2025 .

\section{Conclusion}

The Russian government has not stopped RUSAL, a private company, from chasing after foreign exchange earnings while ignoring interests of domestic producers of investment high added-value goods. However, the chase tripped over the new American president's modern protectionist policy.

Donald J. Trump started protectionism by the Executive Order Buy American and Hire American . Section 1 says (a) "Buy American Laws" means all statutes, regulations, rules, and Executive Orders relating to Federal procurement or Federal grants including those that refer to "Buy American" or "Buy American" that require, or provide a preference for, the purchase or acquisition of goods, products, or materials produced in the United States, including iron, steel, and manufactured goods; (b) "Produced in the United States" means, for iron and steel products, that all manufacturing processes, from the initial melting stage through the application of coatings, occurred in the United States [7].

Almost a year later, based on the ongoing dialogues, President Donald J. Trump authorised the modification of the Section 232 tariffs on steel and aluminium imports to suspend the tariffs for certain countries before they take effect $[8,9]$. These suspensions are based on factors including ongoing discussions regarding measures to reduce global excess capacity in steel and aluminium production by addressing its root causes. Remarks by President Trump at Signing of H.R. 1625: "The trade situation, we will be talking about next week. We have many trade deals, not only the deal being made on South Korea, which 
looks like it is very close to being finalised, but many other countries are now negotiating free trade deals with us. So we will be rolling them out as you see them. And part of the reason, frankly, that we are able to do that is the fact that we have the tariffs on steel and the tariffs on aluminium. Because it showed how unfair some of these trade deals that have been in existence for many years - how unfair they have been" [10].

Due to the circumstances, the Russian government must realise the importance of the state policy for the aluminium industry. The government is responsible for regulating the aluminium market since it is a strategic sector of the state economy. For example, in China, which highly affect non-ferrous metals market, the government has been subsidising lossmaking industries since 2011 and reducing loss-making productions after the 2008 crisis. They created a Reserve Aluminum Fund to support producer and buy metal from producers at low prices, etc. If the Russian government had adapted the measures taken by the Chinese government, we would not have heard the news from LME and COMEX: "LME conditionally suspends placing RUSAL metal on warrant, cites US sanctions".

In view of the current situation and recent events, the world's non-ferrous metals market saw global supply chains of raw materials end in US (25\% of export) and Japan (10\%). Supplies from EU (45\%) are questionable. Russia's government must review its policy in regulating the mining industry by stimulating domestic demand for raw materials of the mining industry by high-technology consumers to produce high added-value goods to ensure sustainable development and, thus, give a pay rise to mincers and engineers.

\section{References}

1. S. Fortescue, Eurasian Geography and Economics, 50:3, 252 (2009)

2. FAS, Principles of Economic Analysis to Verify whether Pricing Practices Comply with the Law "On Protection of Competition" (FAS Russia, Moscow, 2015)

3. A.V. Myaskov, A.S. Ilyin, S.M. Popov, Gornyi Zhurnal, 2, 51-56 (2017)

4. M. Cehlár, J. Janočko, Z. Šimková, T. Pavlik, E3S Web of Conf., 15, 01019 (2017)

5. A. Balabanova, V. Balabanov, E. Dotsenko, N. Ezdina, E3S Web of Conf., 15, 04013 (2017)

6. M. Prekopová, J. Janočko, Geol. Carp., 60:6, 485-494 (2009)

7. Presidential Executive Order on Buy American and Hire American (White House bulleting, Washington, 2017)

8. Presidential Proclamation Adjusting Imports of Aluminium into the United States (White House bulleting, Washington, 2017)

9. Presidential Proclamation Adjusting Imports of Steel into the United States (White House bulleting, Washington, 2017)

10. President Trump Approves Section 232 Tariff Modifications (White House bulleting, Washington, 2017) 